\title{
Changes in the size of the apparent surface area and adsorption energy of the rye roots by low $\mathrm{pH}$ and the presence of aluminium ions induced
}

\author{
Alicja Szatanik-Kloc \\ Institute of Agrophysics, Polish Academy of Sciences, Doświadczalna 4, 20-290 Lublin, Poland
}

Received October 19, 2015; accepted June 15, 2016

\begin{abstract}
A b s t r a c t. The plant reactions on Al-stress include i.a. change of the surface area of the roots, which in the physicochemistry of plants characterizes the transport of water and ions through the root. The object of this study is the specific surface area of the roots of plants which are tolerant to aluminium, such as rye. Plants of rye were grown in a nutrient solution for 14 days at $\mathrm{pH} 4.5$ in the presence of $\mathrm{Al}^{3+}$ ions of concentration 10,20 , and $40 \mathrm{mg} \mathrm{dm}^{-3}$. The control plants were grown continuously at $\mathrm{pH} 7$ or $\mathrm{pH} 4.5$ without $\mathrm{Al}^{3+}$. The apparent surface area and adsorption energy of the plants roots were determined from water vapour adsorption - desorption data. The apparent surface area of roots growing in the aluminium was (with respect to control) statistically significantly lower. There were no statistically significant differences in the apparent surface area of the roots which grew in $\mathrm{pH} 7, \mathrm{pH} 4.5$ without $\mathrm{Al}^{3+}$. The average water vapour adsorption energy of the root surface, under stress conditions decreased. In the roots grown in the presence of $\mathrm{Al}^{+3}$, there was a slight decrease in high energy adsorption centres and an increase in the amount of low-energy centres.

$\mathrm{K}$ e y w o r d s: aluminium, apparent surface area, water vapour adsorption energy, roots
\end{abstract}

\section{INTRODUCTION}

It has been estimated that over $50 \%$ of the world arable lands are acidic (Kochian et al., 2004; Zheng, 2010). Acidification is recognized as the main reason for soil degradation in Poland. Most of the soils in Poland (about 57\%) shows $\mathrm{pH}$ up to 5.5 ie are recognized as very acid (pH up to 4.5) or acid ( $\mathrm{pH} 4.6-5.5$ ) soil categories (Filipek et al., 2006). Hartwell and Pember already in 1918 proved that the major factor limiting the yield of crops on mineral acid soils area aluminium ions (Horst et al., 2010). Aluminium is one of the metals commonly found in the Earth crust, which contains approximately $8 \%$ of this element. The toxi- city of aluminium is not correlated with the total amount of this element in the soil, but its function is the concentration of the forms biologically active the soil solution, which are easily assimilable by the plants. In the soils which have neutral or alkaline reaction, aluminium is present in the form of insoluble oxides and / or silicates, which are not toxic for the plants (Silva, 2012). In the acidic soils $(\mathrm{pH}<5)$, in the soil solution there are soluble compounds of aluminium. Among the soluble compounds of aluminium, inorganic monomeric forms and in particular $\mathrm{Al}^{3+}$ and $\mathrm{Al}_{13}$ are considered to be the most toxic forms (Horst et al., 2010; Panda et al., 2009; Silva, 2012). Aluminium toxicity is a global agricultural problem, severely limiting agricultural productivity for more than half of all the world arable land.

Aluminium is a ballast element, whose role in the physiology of plants is not sufficiently documented. The most recognized symptom of Al toxicity is the inhibition of root elongation (Azura et al., 2011). The toxic impact of aluminium on metabolic and physiological processes as well as morphological, biochemical and anatomical changes of plants has been demonstrated in many studies devoted to these issues (Darco et al., 2004; Panda et al., 2009). In addition, stress activates the roots of a series of defence mechanisms. The main purpose of these mechanisms is to prevent the accumulation of the toxic concentrations of the metal in the sensitive areas of the root cell. Changes associated with toxicity aluminium, lead to inhibition of extracting and transport of water and ions in the roots (Panda et al., 2009). In many mathematical models describing the uptake of water and ions by the roots, the specific surface area is used (Ansari et al., 1995). The specific surface area in the roots of plants is determined by the properties of 
cell apoplast (cell wall and the free intercellular expenses), which create the outer root tissue - the epidermis and cortex primary. The role of the cellular compartment in the detoxification of aluminium is the subject of many studies (Horst et al., 2010).

To estimate the 'specific surface area' of the plants roots, are the sorption methods mostly used. One of such methods is the adsorption-desorption of water vapour. This method has been used for the purpose of this thesis.

In presented study it was hypothesized that the presence of biologically active forms of aluminium in the environment of root growth, and the plants reaction related to this, may affect the change in surface area of the roots. The changes in the surface properties of the roots due to aluminium toxicity have been already noticed i.a. for barley, wheat, triticale (Józefaciuk and Szatanik-Kloc, 2003). The studied species of plants had different resistance / sensitivity to the aluminium, while the rye used in the current studies (Secale cereale L.) has a very good tolerance for acidic ground. This grain has also a high tolerance for an aluminium and manganese ions (Ma et al., 2002; Panda et al., 2009). Learning the tolerant plants reactions to aluminium can contribute to a better understanding of the mechanisms responsible for tolerance to this metal at all.

The aim of this thesis was to determine the changes of the size of the surface area, (one of the physicochemical magnitudes) that characterizes the transport of water and minerals (so-called passive and the short distance transport) in the roots of rye, under the influence of low $\mathrm{pH}$ and aluminium ions.

In addition, base empirical data of adsorption the changes of energy properties of the surface under the influence of stressors have been determined.

\section{MATERIALS AND METHODS}

The plants of winter rye (Secale cereale L.) $c v$. Rostockie were grown in the nutrient solution prepared according to Hoagland (Marschner, 1995), at $\mathrm{pH} 7$ with $16 / 8 \mathrm{~h}$ and 296.2 K/291.2 K (day/night) regime induced with sodium $400 \mathrm{~W}$ lamps (density stream of photons $=300 \mu \mathrm{mol} \mathrm{m}^{-2} \mathrm{~s}^{-1}$ PAR - photosynthetic active radiation), in $5 \mathrm{dm}^{3}$ vessels containing 40 plants each, in three replicates. The water level was controlled and adjusted every day. The solutions were renewed every 7 days. In order to ensure proper aerobic conditions the medium was additionally aerated using the air pumps. In the initial phase of growth and development plants were grown in a medium at $\mathrm{pH} 7$ (Szatanik-Kloc, 2014). The plants were stressed at $\mathrm{pH} 4.5$ during 14 days with different aluminium concentrations 10,20 , and $40 \mathrm{mg} \mathrm{dm}^{-3}$ at shooting stage. Aluminium was added as $\left(\mathrm{AlCl}_{3}\right)$ aluminium chloride. Plants grown continuously at $\mathrm{pH} 7$ and $\mathrm{pH} 4.5$ (without $\mathrm{Al}^{3+}$ ) addition were taken as controls. During the stress the solution $\mathrm{pH}$ was measured and adjusted to the value of 4.5 every $24 \mathrm{~h}$. The
$\mathrm{pH}$ of the medium was maintained at $\mathrm{pH} 7 \pm 0.2$ for the control material and $\mathrm{pH} 4.5 \pm 0.2$ for the stress caused by the low $\mathrm{pH}$ and the presence of aluminium ions. If necessary, the $\mathrm{pH}$ of the medium, to value $(\mathrm{pH} 7$ and $\mathrm{pH} 4.5)$ was adjusted with a $0.1 \mathrm{M} \mathrm{dm}^{-3}$ of potassium hydroxide $(\mathrm{KOH})$ solution and a $0.1 \mathrm{M} \mathrm{dm}^{-3}$ hydrochloric acid $(\mathrm{HCl})$ solution. After 14 days of stress, the roots were separated from the upper parts. The roots were dried for $48 \mathrm{~h}$ at a temperature of $303 \mathrm{~K}$ and collected for further analysis.

Measurement of adsorption - desorption isotherms of water vapour in roots has been performed in accordance with the procedure described in detail in Szatanik-Kloc (2014). The isotherms have been measured in three replicates. The variations in the replicated data did not exceed $5 \%$.Methods of adsorption - desorption of water vapour are based on BET Józefaciuk and Szatanik-Kloc (2003 data from Brunauer et al., 1938) or Aranovich (1992) theory and they enable to describe absolute parameters as well as the heterogeneity of natural sorbent surface, including plant tissues. Simple and thermodynamically correct equation to describe polymolecular adsorption - desorption proposed by Aranovich (1992) has also been used in this thesis. The idea of estimation of the specific surface area is to find a number of adsorbate molecules which cover the root adsorbing surface as a monolayer and to multiply this number by the area occupied by a single molecule. Because the adsorption on organic material are different than with respect to minerals or soils, instead of the name 'surface area' used name the 'apparent surface area' in the method of adsorption-desorption of water vapour. (Szatanik-Kloc, 2014). The apparent surface area and adsorption energies have been calculated using the experimental adsorption desorption data for the $\mathrm{p} / \mathrm{p} 0$ range between $c a .0 .05$ and 0.6 wherein, based on the Aranovich equation there is a monolayer adsorption - statistical monolayer capacity - am. The adsorption energy has been presented as a function of the distribution of adsorption energy, which shows the adsorption centres of different energy (of different strength of binding of the molecule), and as the average adsorption energy. This is due to the presence of the chemically different groups on the root surface, eg carboxylic, hydroxyl, phosphate, amine, peptide. These different surface groups (adsorption sites - centres) bind adsorbate molecules with different strength (and energies), which influences the adsorption pathways. The contribution of different energy sites - centres to the total adsorption can be characterized by the adsorption energy distribution function. The calculations of adsorption energy distribution functions were performed using adsorption data, according to the theory of adsorption on heterogeneous surfaces (Kowalczyk et al., 2004). More details on the above theoretical approach and the calculations of apparent surface area and adsorption energy are presented in Józefaciuk et al. (2013) and Szatanik-Kloc (2014). 
The results were subjected to statistical analysis using the program Statistica version 10.0. In order to test the hypothesis whether aluminium contributed statistically significantly to the change in the surface area of the roots and the average energy of adsorption, the analysis of variance (homogeneity of variance - the Fisher-Snedecor F-test) was used. If the values of the $\mathrm{F}$ test were higher than the values in the tables, it was assumed that the test variances were not homogeneous and therefore aluminium affected statistically significantly the surface area and the average energy of adsorption. In order to determine the concentration of aluminium, which had a significant impact on the changes in the size of apparent surface area and average water vapour adsorption energy of roots, we used the posthoc Test - HSD Tukey, for homogeneous groups $(\alpha=0.05)$

\section{RESULTS AND DISCUSION}

Adsorption - desorption isotherms (in terms of relative pressure adsorbates $\left(\mathrm{p} / \mathrm{p}_{0}\right)$ from 0 to 0.6 of water vapour for roots grown under controlled conditions in the medium $\mathrm{pH} 7$ and $\mathrm{pH} 4.5$ with and without ions of aluminium are shown in Fig. 1. The isotherms, for control $\mathrm{pH} 7$ and for $\mathrm{pH} 4.5$ (without $\mathrm{Al}^{3+}$ ) samples were practically identical for all roots. It indicates that influence of hydrogen ions (at $\mathrm{pH}$ 4.5) on adsorption-desorption properties was insignificant. Protons alone did not alter the roots' physicochemical build-up. The concentrations in the medium of aluminium ions at 10,20 and $40 \mathrm{mg} \mathrm{dm}^{-3}$ decreased the adsorption-desorption for the roots of Secale cereale $\mathrm{L}$.

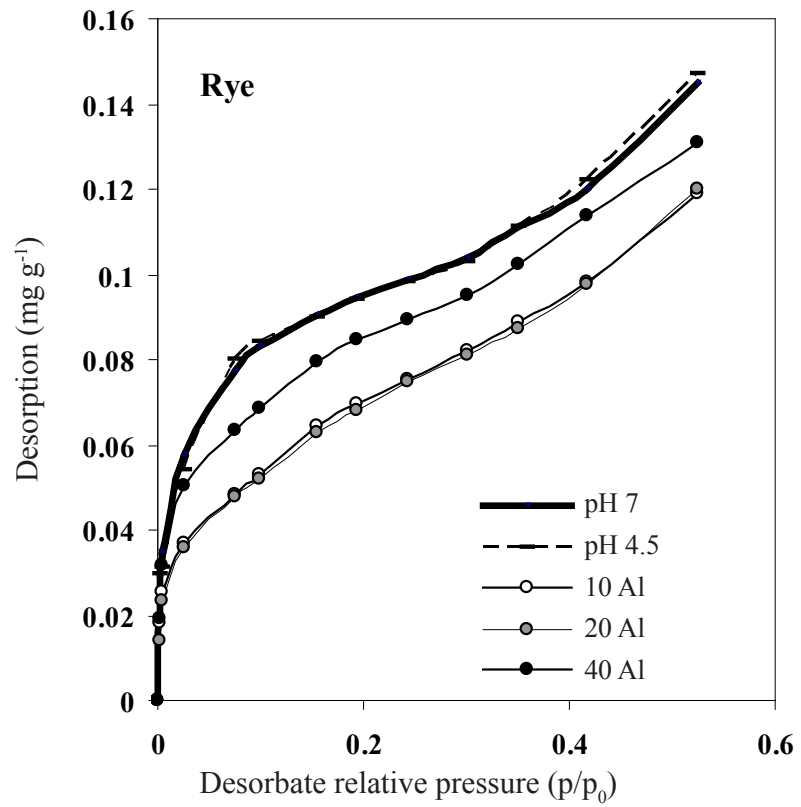

Fig. 1. Water vapour desorption isotherms for Secale cereale L. roots, growing in a nutrient solution prepared according to Hoagland with different of $\mathrm{Al}^{+3}$. The number before the symbol of the element $\mathrm{Al}$ is the amount in $\mathrm{mg} \mathrm{dm}^{-3}$ of aluminium added to nutrient solution.
Quantitative differences in the adsorption - desorption are characterized by the size of root apparent surface area (Table 1). The size of the apparent surface area of roots of Secale cereale L. (cv. Rostockie) decreased in the whole range of the applicable concentrations of aluminium in the medium. There were no statistically significant differences between the size of the apparent surface area of the roots of growing at $\mathrm{pH} 7$ and $\mathrm{pH} 4.5$ (without $\mathrm{Al}^{3+}$ ). For roots that grew in medium with the addition of $\mathrm{Al}$ ions at concentrations of 10,20 and $40 \mathrm{mg} \mathrm{dm}^{-3}$, the size of the apparent surface area was reduced (statistically significant) in comparison to the apparent surface area of control roots. The smallest size of the apparent surface area had the roots that grew in the medium of aluminium ions at a concentration $20 \mathrm{mg} \mathrm{dm}^{-3}$. The size of the apparent surface area of the roots that grew at a concentration of $\mathrm{Al}^{3+}$ ions a $40 \mathrm{mg} \mathrm{dm}^{-3}$ medium had the smallest changes in relation to the apparent surface area of the control roots. Nonetheless, the statistical analysis (Test - HSD Tukey) of the results showed that the presence of aluminium ions (all concentrations used in the experiment) in a root growth of rye, significantly reduced the size of the apparent surface area of the roots in relation to the apparent surface area of the control variant ie the roots of growing at $\mathrm{pH} 7$ and $\mathrm{pH} 4.5$ (without $\mathrm{Al}^{3+}$ ). In the Table 1 there are also presented the average adsorption energies, characterizing the general nature of the root surface energy and its changes under stress. For the roots of rye $c v$. Rostockie, the average energy of adsorption decreased under influence of $\mathrm{Al}^{3+}$. The tendency of changes of adsorption energy is similar to the changes in the apparent surface area of the roots. The lowest average energy of adsorption was observed for roots grown in medium supplemented with aluminium ions in a concentration of

T a b l e 1. Apparent surface area (S) and average adsorption energy $\left(\mathrm{E}_{\mathrm{av}}\right.$ ) of Secale cereale L. of roots (the $\mathrm{S}$ and $\mathrm{E}_{\mathrm{av}}$, values are presented as averages of 3 replications \pm standard deviation)

\begin{tabular}{lcc}
\hline Variance & $\begin{array}{c}\text { Apparent surface } \\
\text { area S }\left(\mathrm{m}^{2} \mathrm{~g}^{-1}\right)\end{array}$ & $\begin{array}{c}\text { Adsorption energy } \\
\mathrm{E}_{\mathrm{av} .}\left(\mathrm{kJ} \mathrm{mol}^{-1}\right)\end{array}$ \\
\hline $\mathrm{pH} 7$ & $423.9 \pm 10.9 \mathrm{a}$ & $16.3 \pm 0.8 \mathrm{a}$ \\
$\mathrm{pH} 4.5$ & $422.8 \pm 11.1 \mathrm{a}$ & $15.9 \pm 0.2 \mathrm{a}$ \\
$\mathrm{pH} 4.5+10 \mathrm{Al}$ & $367.1 \pm 2.4 \mathrm{c}$ & $13.1 \pm 0.1 \mathrm{cb}$ \\
$\mathrm{pH} 4.5+20 \mathrm{Al}$ & $340.3 \pm 15.4 \mathrm{~d}$ & $12.2 \pm 0.05 \mathrm{~d}$ \\
$\mathrm{pH} 4.5+40 \mathrm{Al}$ & $393.6 \pm 4.3 \mathrm{~b}$ & $13.9 \pm 0.2 \mathrm{~b}$ \\
& 56.2 & 56.9 \\
$\mathrm{~F}^{*}$ & $\mathrm{p}=0.000001$ & $\mathrm{p}=0.000001$ \\
\hline
\end{tabular}

*F - the value of the F-test for analysis of variance and the significance level (p) at which the hypothesis of equality of means is rejected. The columns with the same superscript letters indicate the homogeneous groups (no statistically significant difference) HSD Tukey $(\alpha=0.05)$. 
$20 \mathrm{mg} \mathrm{dm}^{-3}$. Adsorption energy frequency distributions for the studied roots are presented in Fig. 2. In the roots that grew in the presence of aluminium, the fractions of high adsorption centres hive been slightly reduced $(\mathrm{E}=$ (Ea-Ec) / RT from -5 to -7) and the fraction of low-energy $(\mathrm{E}=(\mathrm{Ea}-\mathrm{Ec}) / \mathrm{RT}$ from -0.5 to -1.5$)$ adsorption centres has increased. Similarly to the apparent surface area, the changes in the energy performance between the surfaces of the control roots $(\mathrm{pH} 7)$ and those that grew at $\mathrm{pH} 4.5$ without $\mathrm{Al}^{3+}$ have also not been observed.

There is no (statistically significant) influence of $\mathrm{H}^{+}$ ions on the physicochemical properties of the rye roots, which can be explained by the good tolerance of this species of grain on acidic (optimal for growth $\mathrm{pH} 5$ ) soils (Ma et al., 2002; Panda et al., 2009). Furthermore, already in 1942 Arnon and Johnson (cit. after reading Szatanik-Kloc, 2014) reported that hydrogen ions acted adversely on the roots system only at very low $\mathrm{pH}(\mathrm{pH}<3)$ substrate. Therefore, it is assumed that with respect to the acidic soils, mainly $\mathrm{Al}^{3+}$ ions limit the plant growth . The first and the most important symptom of aluminum toxicity is the inhibition of root growth (Azura et al., 2011; Bian et al., 2013; Horst et al., 2010). Szatanik-Kloc (2010) reports that in a rye $c v$. Rostockie there has also been observed a decrease in the root length and dry weight of roots. According to her, the dry mass of roots that grew in $\mathrm{pH} 7>\mathrm{pH} 4.5>$ $10 \mathrm{Al}>20 \mathrm{Al}>40 \mathrm{Al}$, amounted to: in mg / plant (av. of 10 plants in 3 repetitions) $0.025=0.025>0.024>0.023$ $>0.019$ while, the total root length of rye (av. of 9 plants) decreased (relative to the control), by about $10 \mathrm{Al}-9 \%$, $20 \mathrm{Al}-15 \%$, and $\mathrm{Al} 40-32 \%$. In the same publication it is also reported that the roots of rye growing in the medium of aluminum ions at concentrations of 20 and $40 \mathrm{mg} \mathrm{dm}^{-3}$ clearly increased root diameter in relation to the roots of the other variants experiment.

Inhibition of root growth and increasing root diameter is closely associated with the Al-induced changes, processes to physiological, metabolic and molecular level, which may lead to morphological and structural changes in the root (Silva, 2012).

Besides the inhibition of root elongation growth, Al-induced inhibition of the production of cellulose and increased production callose has been reported. Teraoka et al. (2002) report that callose has been produced simultaneously with the inhibition of cellulose, inversely proportionally to the reduction of cellulose. At the same time, these changes were more severe in barley and Al-sensitive wheat than in Al-tolerant wheat $c v$. Atlas 66. The callose (a glucose polymer) is deposited on the outside of the cell wall. The production of the enzyme (beta-1,3-glucan) inhibiting the synthesis of callose by the presence of metal depends on the electrical potential of the composition and properties of the cell membrane and the intracellular $\mathrm{Ca}^{2+}$. Cytosolic $\mathrm{Ca}$ is one of the conditions for the induction of synthesis of callose (Panda et al., 2009).

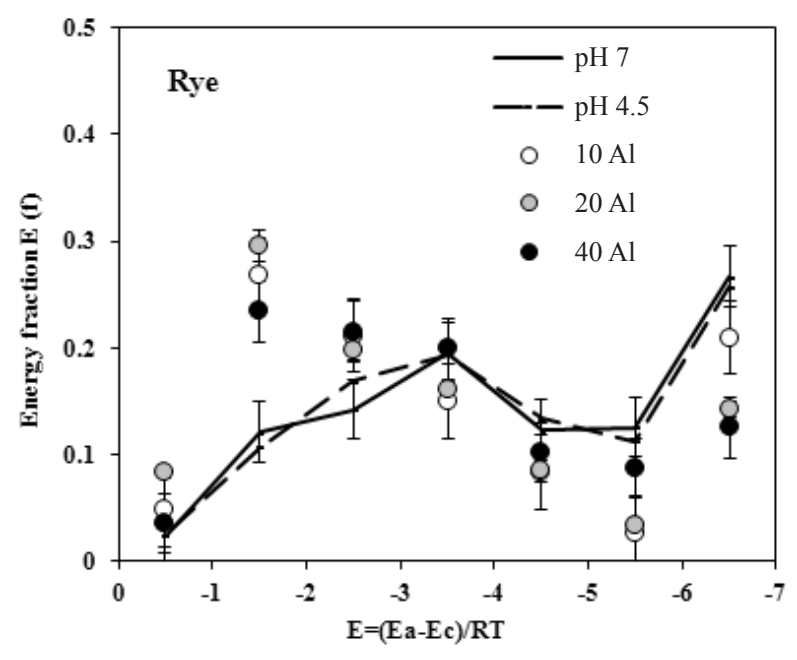

Fig. 2. Adsorption energy distribution functions for roots of Secale cereale L. growing in a nutrient solution with different content of $\mathrm{Al}^{+3}$ (points in the figure represent the individual fraction of energy and are the mean values of 3 replicates \pm SD error bars).

In the rye roots $c v$. Rostockie, exposed to Al-stress, there was generally less calcium content ie $\mathrm{pH} 7$ and pH $4.5-8.7$ and $8.1 \mathrm{mg} \mathrm{kg}^{-1}$ d.m., respectively; $10 \mathrm{Al}$, $20 \mathrm{Al}$, and $40 \mathrm{Al}: 4.4,3.3$, and $2.9 \mathrm{mg} \mathrm{kg}^{-1}$ d.m., respectively (Szatanik-Kloc, 2010). These data are consistent with data obtained by Silva et al. (2012), who showed that, in the less line of the rye (during exposure to aluminium) the $\mathrm{Ca}$ content has decreased. However, the authors have reported an increase the content of intracellular (cytosolic) and $\mathrm{Ca}^{2+}$ and deposition of callose.

Therefore it is likely that $\mathrm{Al}$ - induced callose deposition in the cell wall may alter the surface properties of roots, and so it may also be responsible for a change (decrease) in apparent surface area in the examined roots of rye.

Since the size of the apparent surface area of the root depends on the properties of apoplast cells (ie cell wall and the intercellular space) which form the outer body of the root system ie rhizoderma and primary cortex, the changes related to the influence of $\mathrm{Al}^{3+}$ in that area of the root are likely to cause the changes in the physicochemical properties such as the apparent surface area. These changes are also caused by the presence in the apoplast so-called resistance mechanisms to aluminium.

In the course of evolution plants have developed both adaptation and acclimatization mechanisms of stress tolerance (Matuszak-Slamani and Brzóstowicz, 2015). Research showed that there were two classes of mechanisms $\mathrm{Al}$ - tolerance. Determination of strategy of tolerance can be divided into mechanisms associated with the exclusion of aluminium and a tolerance of plants on the concentration of aluminium in the symplast. This second mechanism is the typical feature of the species accumulating aluminium. This mechanism was noted for hydrangea (Naumann and Horst, 2003), and tea (Carr et al., 2003). The majority of 
plants is dominated by first-class mechanism of toleranceexclusion. These mechanisms operate at appolast and / or the rhizosphere, which task is to prevent the penetration of aluminium to the sensitive areas of the root cells.

One of the mechanisms of tolerance to aluminium may be increased secretion of organic acids. For example, there has been found a strong correlation between the degree of resistance to aluminium and the size of the Al-induced secretion of malate in many genotypes of wheat (Ryan et al., 1995). Li et al. (2000) reported that the total amount of Al-induced secretion organic acids was greater in the rye's roots than that in the wheat. Al-tolerant maize genotype also exuded more organic acids than $\mathrm{Al}$-sensitive $c v$. Lixis (Eticha et al., 2005). Yang et al. (2011) observed the increased secretion of oxalic acid in the roots of the different genotypes Fagopyrum tataricum L. exposed to Al-stress.

The presence of these acids in the apoplast can cause an increase of adsorption centers with low energy, which has been observed in the experiment. Furthermore, Bian et al. (2013) have also observed increased secretion of phenolic compounds, and phosphates, which can prevent the penetration and $\mathrm{Al}$ accumulation in the cells, which may also cause an increase in the fraction (centers) of low energy.

Another mechanism can be pectic acids of the cell walls, which forms a mechanical and chemical barrier to the penetration of the free metal to symplastu, as demonstrated for $\mathrm{Cu}, \mathrm{Zn}, \mathrm{Pb}$, and low concentrations of $\mathrm{Al}$. In particular, pectin acids are recognized as effective chelating agents aluminium ions. Pectins are ones of the main components of cell wall of all higher plants and generally they are about one third of the total mass of the cell wall. In fact, the content of pectin does not determine the chelating of aluminium ions in the cell wall, but a negative charge, associated with the degree of methylation (DM) of the pectin, which is controlled by pectin methylesterase (PME). Non methylated carboxyl groups $\left(\mathrm{COO}^{-}\right)$of pectin are the most likely candidate to bind $\mathrm{Al}^{3+}$ (Eticha et al., 2005).

Non methylated carboxyl groups are also the main groups that are characterized by polar adsorption sites. Thus, the binding of the aluminium .with the carboxylic

a

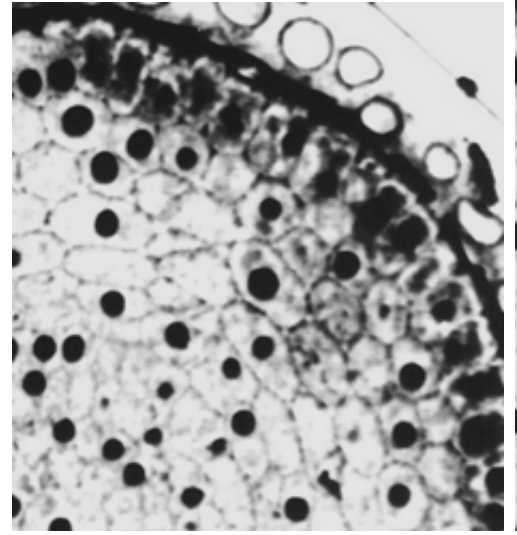

groups of the cell wall can help to reduce the number of high adsorption sites (Fig. 2), $(\mathrm{E}=(\mathrm{Ea}-\mathrm{Ec}) / \mathrm{RT}$ from -5 to -7), responsible for the adsorption energy of the polar adsorbate-water vapour and consequently to reduce the average adsorption energy, as well as a reduction in the 'apparent surface area' of the rye root, which was observed in this experiment.

It also showed that the aluminium collected in the apoplast modifies the cell wall composition and its properties, including the content of pectin and the degree of their methylation (Horst et al., 2010; Schmohl et al., 2000). Generally, it has been hypothesized that a low content of pectin and/or a high degree of methylation of the pectin contribute to the resistance on aluminium.

Thus, the potential changes to the structure of the pectin of the rye $c v$. Rostockie, could affect the physicochemical parameters investigated. This will be the focus of our future research.

With respect to the majority of species (varieties) of cereals, such as barley, wheat or triticale tested so far, exposed to Al-stress it has been reported an increase in the apparent surface of roots in comparison with roots growing in the optimal conditions (Józefaciuk and Szatanik-Kloc, 2003). In the roots of these plants there has been observed a deformation of the cell wall in the outer root tissue, causing exposure of new and chemically different surface.

In the roots of Secale cereale L. (cv. Rostockie), the similar reaction has not been noticed, even at the highest $\left(40 \mathrm{mg} \mathrm{dm}^{-3}\right)$ aluminium concentration in the culture medium (Fig. 3).

According to the Anioł and Madej (1996) among the varieties and inbred lines Secale, aluminium sensitivity occurs when the metal concentration is above $68 \mathrm{ppm}$. Thus, the concentration of aluminium ions in medium used in the experiment cannot be lethal and/or sub - lethal for the tested rye, and the reduction in 'apparent surface area' of the roots and the average energy of adsorption, was rather associated with the mechanisms of resistance to aluminium than with the destruction of the tissues of roots. However, it appears that the activity of plant defense reactions depends on the intensity (magnitude) of $\mathrm{Al}$ - stress.

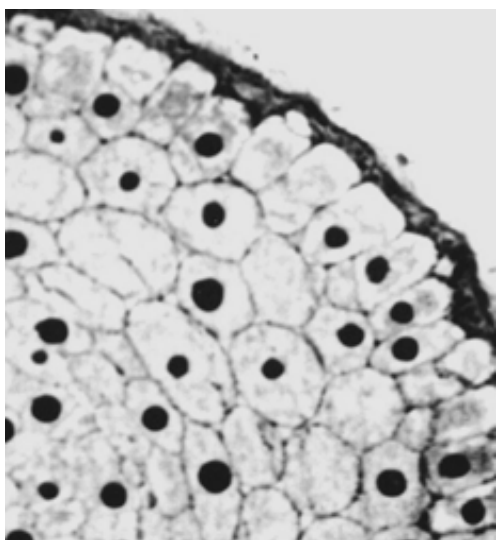

$\mathrm{b}$

Fig. 3. Cross-sections of apical meristem of the rye root (x 400): a - control without $\mathrm{Al}^{3+}$ and $\mathrm{b}$ - with $40 \mathrm{mg} \mathrm{dm} \mathrm{dl}^{-3} \mathrm{Al}$ ions. 
However, it appears that the activity of plant defense reactions depends on the intensity (magnitude) of $\mathrm{Al}$ - stress. The greatest changes (relative to control variant) in the stress at $20 \mathrm{Al} \mathrm{mg} \mathrm{dm}^{-3}$ were observed. However, at higher (40 Al $\mathrm{mg} \mathrm{dm}^{-3}$ ) stress, changes in the physicochemical parameters studied were the smallest, which may be due to the limited role of the defense mechanisms in the aluminium concentration.

This may explain the differences, the trend in the changes (under the influence of the concentration used in the experiment of aluminium), of the apparent surface area and average energy of adsorption, between the rye $c v$. Rostockie and other tested plants so far.

The binding of Al to pectin matrix and other cell wall components, as well as the Al-induced callose deposition or production of organic acids can change the properties of the cell walls and their functions, and thus will have a significant impact on the physicochemical properties of the root surface. In general, stress syndrome Al in all plant is similar; the only differences are due to the genotypic resistance / sensitivity, which mean that the resistant plants only at a much higher concentration of aluminum will have similar signs of toxicity (eg destruction of the tissues) which may lead to an increase in the apparent surface area of the roots. At low concentrations of aluminum, changes in the physicochemical properties of the roots (eg reducing the apparent surface area, increase in the low-energy and decrease in the high-energy of the adsorption centers) are likely to depend on the activity of the defense mechanisms of the plants.

\section{CONCLUSIONS}

1. The roots grown at doses $\left(10,20\right.$ and $\left.40 \mathrm{mg} \mathrm{dm}^{-3}\right)$ $\mathrm{Al}$ ions used in the experiment were characterized by lower apparent surface area and lower average energy of adsorption of water vapour in relation to the roots of control objects.

2. Changes in the physicochemical properties were statistically significant, but not directly proportional to the concentration of the stress factor. The smallest apparent surface area and average adsorption energy, was observed for roots growing at $\mathrm{Al}$ ion concentration of $20 \mathrm{mg} \mathrm{dm}^{-3}$. At the roots, which were grown in the medium supplemented with aluminum ions in a concentration of $40 \mathrm{mg}$ $\mathrm{dm}^{-3}$, changes in the tested parameters were the smallest in respect to the control roots.

3. There was no significant effect on the physicochemical properties investigated of hydrogen ion concentration ( $\mathrm{pH} 4.5)$ in the embodiment of experience base additive of aluminum ions.

Conflict of interest: The Authors do not declare conflict of interest.

\section{REFERENCES}

Anioł A. and Madej L., 1996. Genetic variation for aluminium tolerance in rye. Vortr. Pflanzenz, 35, 201-211.

Ansari S.A., Pramod Kumar, and Gupta B.N., 1995. Root surface area measurements based on adsorption and desorption of nitrite. Plant Soil, 171, 133-137.

Aranovich G.L., 1992. The theory of polymolecular adsorption. Longmuir, 3, 736-739.

Azura A.E., Shamshuddin J., and Fauziah C.I., 2011. Root elongation, Root surface area and organic acid by rice seedling under $\mathrm{Al}^{+3}$ and/ or $\mathrm{H}^{+}$stress. American J. Agric. Biol. Sci., 6(3), 324-331, doi: 10.3844/ajabssp.2011.324.331

Bian M., Zhou M., Sun D., and Li C., 2013. Molecular approaches unravel the mechanism of acid soil tolerance in plants. Crop J., 1(2), 91-104, doi:10.1016/j.cj.2013.08.002

Carr H.P., Lombi E., Küpper H., McGrath S.P., and Wong M.H., 2003. Accumulation and distribution of aluminium and other elements in tea (Camellia sinensis) leaves. Agronomie, 23, 705-710, doi: 10.1051/agro:2003045

Darco E., Ambrus H., Syefanovits-Banyai E., Fodor J., Bakos F., and Barnabas B., 2004. Aluminium toxicity, Al tolerance and oxidative stress in Al-sensitive wheat genotype and Al-tolerance lines developed by in vitro microscope selection. Plant Sci., 166, 583-591, doi: 10.1016/j.plantsci. 2003.10.023

Eticha D., Stass A., and Horst W.J., 2005. Cell-wall pectin and its degree of methylation in the maize root-apex: significance for genotypic differences in aluminium resistance. Plant, Cell Environment, 28(11), 1410-1420, doi: 10.1111/ j.1365-3040.2005.01375.x

Filipek T., Fotyma M., and Lipinski W., 2006. Condition, the causes and effects of acidification of arable soils in Poland (in Polish). Fertilizers Fertilization, 2(27), 7-38.

Horst W.J., Wang Y., and Eticha D., 2010. The role of the root apoplast in aluminium - induced inhibition of root elongation and in aluminium resistance of plants: a review. Annals Botany, 106, 185-197, http://dx.doi.org 10.1093/aob/mcq053

Józefaciuk G., Lukowska M., and Szerement J., 2013. Determination of energetic and geometric properties of plant roots specific surface from adsorption/desorption isotherm. American J. Plant Sci., 4, 1554-1561, http://dx.doi.org/ 10.4236/ajps.2013.48187

Józefaciuk G. and Szatanik-Kloc A., 2003. Changes in specific area and energy of root surface of cereal plants in Al-solution cultures. Water vapor adsorption studies. Plant Soil, 250(1), 129-140, doi:10.1023/A:1022813018940

Kochian L.V., Hoekenga O.A., and Pĩneros M.A., 2004. How do crop plants tolerate acid soils? Mechanisms of aluminium tolerance and Phosphorous efficiency. Plant Biol., 55, 459-93, doi: 10.1146/annurev.arplant.55.031903.141655

Kowalczyk P., Tanaka H., Kanoh H., and Kaneko K., 2004. Adsorption energy distribution function from the Aranovich-Donohue lattice density functional theory. Langmuir, 20(6), 2324-2332, doi:10.1021/la035748k

Li X.F., Ma J.F., and Matsumoto H., 2000. Pattern of Al-induced secretion of organic acid differs between rye and wheat. Plant Physiology, 123, 1537-1543, http://dx.doi.org/10. 1104/pp.123.4.1537 
Ma Q., Rangel Z., and Kuo J., 2002. Aluminium toxicity in rye (Secale cereale L.): Root growth and dynamics of cytoplasmic $\mathrm{Ca}^{+2}$ in intact root tips. Annals Botany, 89, 241-244, doi: $10.1093 / \mathrm{aob} / \mathrm{mcf0} 17$

Matuszak-Slamani R. and Brzóstowicz A., 2015. Influence of salt stress on growth and frost resistance of three winter cereals. Int. Agrophys., 29, 193-200, doi: 10.1515/intag2015-0018

Marschner H., 1995. Mineral Nutrition of Higher Plants. Academic Press, London, UK.

Naumann A. and Horst W.J., 2003. Effect of aluminium supply on aluminium uptake, translocation and blueing of Hydrangea macrophylla (Thunb.) Ser. cultivars in a peat-clay substrate. J. Horticultural Sci. Biotechnol., 78, 463-469.

Panda S.K., Baluska F., and Matsumoto H., 2009. Aluminium stress signalling in plants. Plant Signal Behav., 4(7), 592597, doi: $10.4161 /$ psb.4.7.8903

Ryan P.R., Delhaize E., and Randall P.J., 1995. Characterization of Al-stimulated efflux of malate from the apices of Al-tolerant wheat roots. Planta, 196, 103-110.

Schmohl N., Pilling J., Fisahn J., and Horst W.J., 2000. Pectin methylesterase modulates aluminium sensitivity in Zea mays and Solanum tuberosum. Physiol. Plantarum, 109, 419-427.
Silva S., 2012. Aluminium toxicity targets in plants. J. Botany Article ID 219462, 8 pages, http://dx.doi.org/10.1155/ 2012/219462

Silva S., Santos C., Matos M., and Pinto-Carnide O., 2012. Al toxicity mechanisms in tolerant and sensitive rye genotypes. Environ. Exp. Botany, 75, 89-97, doi:10.1016/j. envexpbot.2011.08.017

Szatanik-Kloc A., 2010. Changes in surface properties of plant roots determined by aluminium and copper phytotoxicity. (in Polish). Acta Agrophysica, 176(1), 1-120.

Szatanik-Kloc A., 2014. Application of adsorption methods to determine the effect of $\mathrm{pH}$ and $\mathrm{Cu}$-stress on the changes in the surface properties of the roots. Int. Agrophys., 28, 511520, doi: 10.2478/intag-2014-0041

Teraoka T., Kaneko M., Mori S., and Yoshimura E., 2002. Aluminum rapidly inhibits cellulose synthesis in roots of barley and wheat seedlings. J. Plant Physiology, 159(1), 17-23.

Yang J.L., Zhu X.F., Zhang Y.J., and Zheng S.J., 2011. Genotypic differences in $\mathrm{Al}$ resistance and the role of cell wall pectin in $\mathrm{Al}$ exclusion from the root apex in Fagopyrum tatarcium L. Annals Botany, 107, 371-378, doi: 10.1093/ aob/mcq254

Zheng S.J., 2010. Crop production on acid soils: overcoming aluminium toxicity and phosphorus deficiency. Annals Botany, 106, 183-184, doi: 10.1093/aob/mcq134 